\title{
ENTERPRISES PERFORMANCE THROUGH INTERNAL RESOURCE INTEGRATION AND MARKET ORIENTATION BASED ON COMPETITIVE ADVANTAGES
}

\author{
Purwohandoko *)
}

\begin{abstract}
Every company tries to achieve goals to gain profit and win the competition. To achieve this goal, the company must be able to demonstrate a competitive advantage. Therefore, the company always strives to gain competitive advantage by identifying, managing and optimizing their internal resources in the form of tangible and intangible assets that have superior characteristics as the power of generating competitive advantage. The sustainable competitive advantage by empowering their internal company resources can be defined as Research-Based View (RBV). The importance of research based views is contradicting with Market Based View (MBV) which stated that the more market oriented the more superior their competitive position. By using qualitative research (literature review), this study aims to understand and investigate how to create company performances through both point of views which is internal resources integration and market orientation based on competitive advantages.
\end{abstract}

\section{Keywords: Resources, Competitive Strategy, Competitive Advantages}

\section{INTRODUCTION}

\subsection{Research Background}

Globalization has led to an increasingly complex level of competition. It requires companies to increase their competence in building a winning marketing strategy. Companies that want to be written by our customers after their stay in the business world must always be responsive to the global market situation. Every company tries to achieve goals to gain profit and win the competition. To achieve this goal, the company must be able to demonstrate a competitive advantage. As an organization, companies consist of several resources if they are managed properly, this will result in a competitive advantage. Phenomenon that occurred in Indonesia raises the question, why many companies go bankrupt when the market opportunity is open, why other companies can survive and even grow, and what factors make the company have sustainable competitive advantage? The corporate bankruptcy phenomenon, if related to relatively stable number of customers and increased Product Offerings, it will indirectly increase the level of competition between companies. They suggest that: first, a set of productive resources can be controlled among different companies, even in the same industry and second, the definition of a productive source is broader than the Ricardian definition; and third, entrepreneurial additional productive resources to be considered by the company. Barney (1991a) suggested that the company's competitive advantage lies in the availability of resources and features that have characteristics of difficult to imitate by other companies. Every company may not operate the same resources, because even if resources are limited, they have different priorities in allocating and assessing the importance of generating competitive advantage. The sustainable competitive advantage, power resource that is more focused resources internal company resources reinforced by Priem \& Butler (2001a) stating that companies should incorporate the concept of Research-Based View (RBV) or the perspectives of their resource firms to clarify the criteria for measurement, so it can contribute to improve the company's performance. The view of how to generate competitive advantage is controversy (Hooley, et al.). The importance of competitive strategy, in conjunction with the company's ability to determine the right strategy in a variety of company decisions, will be able to produce an optimal competitive advantage Priem \& Butler (2001b). Each company will ultimately determine the form of approach or strategy to achieve the company's goals, resulting in return on investment will be removed, and the best strategy for the company will eventually be a distinctive construction that reflects its own situation so as to improve the company's performance. 
As in previous studies, such as studies by Makinen (2000), Matsuno \& Mentzer (2000), and Matsuno, Mentzer, \& Remtz (2005) that concluded that competitive strategies have a positive effect on company performance.

\subsection{Research Problem}

Based on the above reasoning, researcher need to investigate how to create company performances through internal resources integration and market orientation based on competitive advantages.

\subsection{Research Purpose}

The purpose of this research is to studies literature about how to create company performances through internal resources integration and market orientation based on competitive advantages.

\section{THEORETICAL FRAMEWORK}

\subsection{Theoretical Framework}

\subsubsection{Company Resources}

Resources can be defined as environmental elements which consist of human resources, natural resources, non-biological resources and human resources (UU No. 4 of 1982). Thus, all sources whether human, material and real energy and can potentially be used to improve human well-being called resources. Resources are divided into two categories: tangible and intangible. Real resources consist of all physical items owned by the company, raw materials, and all equipment. Meanwhile, intangible resources do not appear in raw material and balance sheet statements. Examples of intangible resources are corporate culture, reputation, and internal control. Therefore, it is very interesting to conduct research on the potential of resources that can enhance sustainable competitive advantage in the company. Robert M. Grant Resources (1991) is classified into six major groups, namely: financial resources, physical resources, human resources, technological resources, reputation, and organizational resources. The main function of an approach-based resource to formulate a strategy is to maximize the rebate gradually. This is related to the opportunities that can be taken to make resource utilization more economical. The ability to maximize productivity is critical. To achieve this we need to strive for available resources to support larger volumes for businesses. The Research-Based View (RBV) theory is developed to generate competitive advantage that can be built of four sources, namely : (1) Unique traditional study of competence (2) Ricardian economics, economics (3) Penrosian, and (4) Antitrust economic impact assessment (Barney \& Arikan, 2000). ). In 1959, Barney \& Arikan (2000) published a book called the theory of corporate growth. The company sees it as a function of production (just like Ricardian theory), but its development and contribution to RBV is, first, a set of productive sources that can be controlled by companies is different even in the same industry, second, a broader definition of source of the product of the Ricardian definition only focus on some types of productive resources; third, the diversity of productive sources of the company is added to entrepreneurial resources. Barney \& Arikan (2000) suggests that company is a collection of productive resources and economic value of resources. The ability of resources to be non replicable depends on how far the resources are protected by isolating mechanisms. Competitive advantage can be realized if the company has implemented a holistic strategy and value creation compared to its competitors (Barney, 1991b). That is, competitive advantage can still be easily and quickly imitated by competitors, so room (AC) resources are needed to prevent other companies. Dollinger (1999) disclassified 6 sources which are able to create a sustainable competitive advantage, namely (1) physical (2) reputation, (3) organization, (4) finance, (5) intellectual/human, and (6) technology that made clear as below. Hitt, et al., (1999) defines resources as inputs in the company's production processes, such as goods, employee, patent, financial and managerial skills, so in general resources includes a wide spectrum of individual, social and organizational phenomena. Some experts provide 
source characteristics, which have and produce competitive advantages, such as Barney (1991b), having something of value, rare, imitated and irreplaceable. The characteristics of resources that produce competitive advantage provided by experts are different from each other, including: valuable, rare, unreplicable, unreplacebale, superior and durable. Some opinions on the definition of these resources have the same principle, derived from the perspective of the importance of resources to produce sustainable competitive advantage so that internal sources are defined as one company of tangible assets, or dynamic capabilities, or core competencies, owned by the firm to produce values that are not easily imitated by other companies and used to determine and implement competitive strategies.

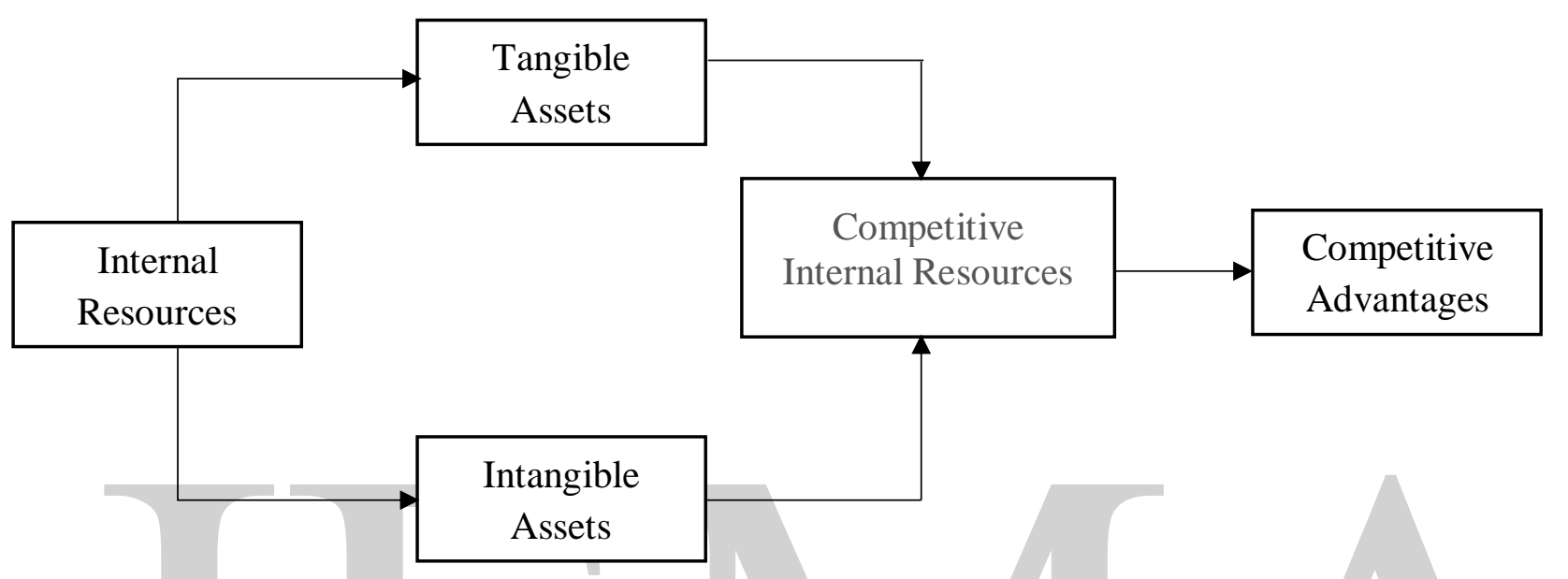

Picture 1 Competitive Internal Resources

Purwohandoko (2010) stated that the company always strives to gain competitive advantage by identifying, managing and optimizing internal resources in the form of tangible and intangible assets that have superior characteristics as the power of generating competitive advantage. To be more precise, a company can identify, manage and optimize internal resources, strong internal resources results competitive advantage. Each company has different resources, which impact on the difference efficiency and profit and heterogeneity resource, which can be optimized by the company, causing diversity gain. This is the determinant of every performance. The company's resources obtain at lower price, compared to current price, or competitor's price. Those are the company's competitive advantage because the same resources will produce the same benefits but at a cheaper cost, so the company becomes easier to sell products and get bigger profits.

\subsubsection{Strategy}

A competitive strategy is the thought that come up from Michael E. Porter to provide a deep understanding of the company's managers, about industry and competitors in running the company's activities. An explicit strategy of development through the planning process (Craig \& Grant, 1999), or it may have been implicitly developed through the activities of various functional departments. Strategy is a way of decision or action that requires top management and requires a lot of company resources to make it happen, so that, the future is strategy-oriented because it affects in the long term of organizational life, and it has multifunctional or multidivisional consequences (David, 2003). Because the strategy has multidivisional consequences, analysis of internal and external factors faced by the company needs to be done so that the company does not make mistakes in the formulation of competitive strategy. Porter (1980) defined competitive strategies into three types, namely cost leadership, differentiation and focus. The main purpose of cost leadership is to create a large market share, thereby increasing production capacity. Differentiation strategies are strategies that produce unique products or provide different values to build customer brand loyalty, avoid customer price sensitivity and creating an entry barrier for competitors to make a profit. Strategic 
focus is a strategy that focuses on a particular segment of competition by consumer type, product or geography. Porter's generic concept of competitive strategy includes cost leadership, differentiation, and focus. In practice, there is no strategy implemented in the pure, but by integrating cost leadership and differentiation strategies. This strategy seeks to create uniqueness/differentiation but at low cost. Or in other words, although the price is cheaper, the quality can be compared. Low cost integration and strategy differentiation can be applied if there is variation from consumer desire, but they are also price sensitive (Mitchell, 2004). To be successful in implementing this strategy, companies need resources, skills, and ability to increase cost (up-scale) of lower attribute product quality attributes in with than competitors. The emergence of this integration strategy shows that the company does not implement a pure basic strategy. That is, the tendency of basic strategy (low cost, differentiation, or focus) is still needed, but the company can also add attributes from other strategies. Makinen \& Mentzer (2000); Matsuno and Mentzer (2000), Matsuno, Mentzer, \& Remtz, (2005); Studies state that through the development of competitive strategies it can be explained how companies can use the potential of strategy (empowerment) to build strong resources for competitive advantage. Twomey\& Drew (2000) said that a strategy based on internal resources as a unique source that is not easily duplicated can lead to a competitive advantage. Purwohandoko (2010) added that the company always seeks to gain a competitive advantage by using the power of internal resources and responding to change market dynamics through market orientation and external environment and to formulate and implement appropriate competitive strategies to generate competitive advantage. The stronger the internal source and implementation of market orientation which are used as basis for formulating competitive strategies, the better implementation of competitive strategies in generating competitive advantage.

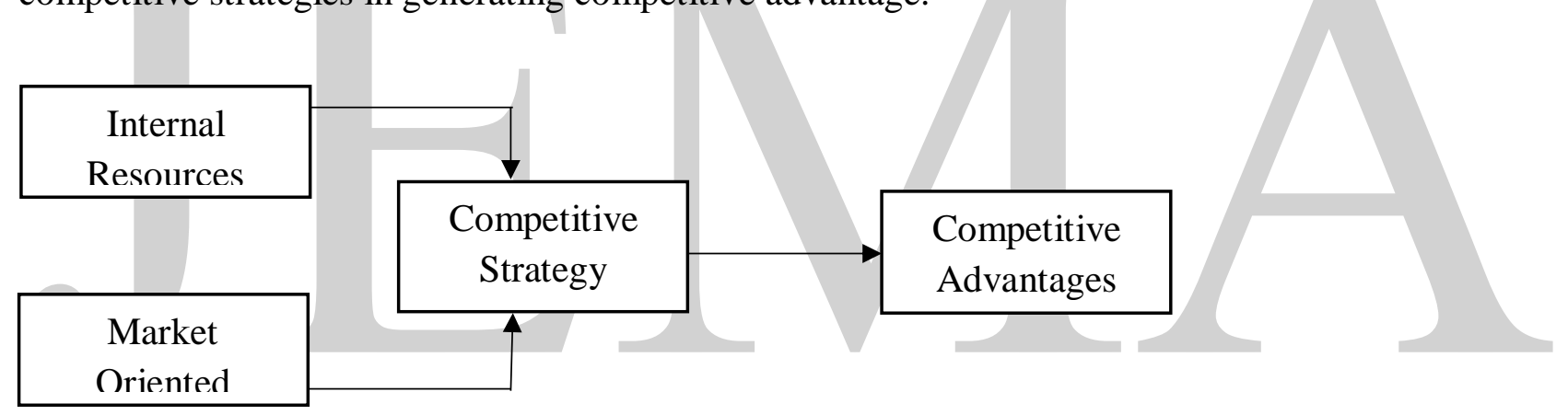

Picture 2 Competitive Strategy and Competitive Advantages

\subsubsection{Competitive Advantages}

Each company may not operate the same resources, because even if their resources are limited, they have different priorities in allocating and assessing the importance of the company's competitive advantage. Not all involved is considered a competitor in competitive advantage of business environment, but only the potential competitors as well as those who have entered the competition as well as potential competitors in the business. The company will be glad to have a sustainable competitive advantage and does not get stimulus to review the advantages of its competitors (Barney, 1991). Sustainable competitive advantage does not have a time limit. It is different from instantaneous competitive advantage. So, a sustainable competitive advantage is an advantage that has a very long period of time (Porter, 1996). Competitive advantage is a strong unity between corporate excellence and organizational effectiveness adapt to environmental change. Competitive advantage is a translation of fact which is the process of identifying, developing and placing a real advantage. All resources that support company's competitive advantage are often used as research, as the basis of the strategies implemented in company's management (Porter, 1996). Basic unification of your competitive advantage capabilities and organizational resources are important determinants to become a relative position and better performance than competitors. The company's performance will in particular be the basis for building a source that has a competitive 
advantage. Competitive advantage will build skills for activities performance that are more than business opponents, or more effective than competitors, in other words, companies build competitive advantage when harnessing power for some activities more than their performance (Kaplan \& Norton, 1996). The high-capacity increase of source code that results in low cost and increased value to customers is the advantage of position control. According to Barney (1991b), there are three main sources of the company, namely: (1) source of physical capital (technology, building, equipment, location, and access to material), (2) human resources (training, experience, assessment, relationships, and individual tasks), capital resources (3) organization (structure, formal and informal planning, oversight, and coordination system, which is a group relationship with the company and the relationship between the company and the environment). Aaker (1991) developed a theory of sustainable competitive advantage based on resources, so it complementing Porter's (1980) theory of sustainable competitive advantage based on company's product market position. This approach assumes that the market portfolio of the market position taken by the company is reflected in the source portfolio power controlled by the company. Contribute in the development of resource-based theories provided by Wernerfelt. Profile resources are the competition among companies that can encourage companies to gain competitive advantage through the implementation of competitive strategies. The competitive advantage of a company can be made through enhancement of company performance. Kaplan \& Norton (2004) formulated the Company's performance measurements derived from a balanced vision and strategy through four perspectives: (1) customers, business processes (2) internal, (3) learning and growth, and (4) finance. The balance in question is the balance in the various internal and external sizes, current size and size of future performance drivers, as well steps of outcome subjective and objective, so the company can use the scorecard as a strategic management system to manage long-term strategies (Kaplan \& Norton, 1992).

\subsubsection{The Resources Based View (RBV)}

$\mathrm{RBV}$ is a source of competitive advantage. In the view of RBV, the existence of corporate resources is a source of competitive advantage, because the present of Company will build competence. In contrast, in a market-based view, market-oriented strategy will put the company in a superior competitive position. Through a market-driven approach, companies can engage in effective market-oriented strategies. Emphasis on one component in company's resources becomes unrealistic and risky for the company's long-term viability. Pursuing the fulfillment of consumer needs and wants, and reacting to competition is impossible to do if it is not supported by adequate resources. Collis \& Mongomery (1998) promoted the need for attention that must be taken into account in formulating a strategy. The first is the external position. The company must be able to recognize the competitor in the industry through the strengths, weaknesses, opportunities, or threats, so that strategies can be formulated and implemented to build a competitive advantage in making profit. In the meantime, this is an internal alignment. Strategy will clarify the position of the product market, so the company must respond and coordinate in all management functions, ranging from $\mathrm{R} \& \mathrm{D}$ to marketing. The strategy is the energy in the growth of competing company's ability to be formulated from creative responses of internal and external changes. The company will gain a higher position in the market more quickly and appropriately in response to the dynamic changing needs of consumers and desire as well as its competitor movement, and make reconstruction of the market structure.

\section{RESEARCH METHOD}

This research can be classified as qualitative research. This work is a literature study that can be applied to a business organization by applying an internal resource component which is The Resources Based View (RBV). The internal source being examined is tangible and intangible. The study does not use the sample because it is only a literature study. 


\section{RESEARCH RESULT AND ANALYSIS}

\subsection{Potential Impact}

The companies tend to have the advantage of rare inputs, raw materials that cannot be reproduced or limited in number, and need to apply production factors that require large capital requirements with complex characteristics, demanding highly competitive strategy accuracy. The development of competitive strategies, it can be explained how companies can use potential strategies (empowerment) to build strong resources for competitive advantage. Twomey\& Drew (2000) suggested that strategies based on internal resources as unique and non-duplicable sources can produce competitive advantage. When companies understand how to use resources to apply competitive strategies that can be a source of competitive advantage, the application will be in line with the competitive strategy chosen by the company (Barney \& Arikan, 2000). Greer (2003) explains that human resources as one of the company's resources can generate contribution in creating strategy. Michael Porter also found that human resource management is key in creating competitive strategies.

In some organizational development, human resources are the source of a competitive strategy (Porter in Greer, 2003). Large-scale business enterprises tend to have stronger internal resources rather than Company's small scale business. They also have strong competitive advantages, tendency of choice and implementation of low cost competitive strategies. Conversely, small-scale enterprises (small and medium scale), with limited internal resources, tend to choose and apply strategies to compete with strategies focus. For small-to medium scale companies, the choice of strategy is the focus of a more objective choice, because in order to compete with the cost of leadership strategy in the broader market, companies require mastery of economic requirements of scale and wide distribution of networks that are naturally difficult to meet because various internal resource constraints. The main objective of a competitive strategy is to gain a competitive advantage. A competitive advantage can be gained only if the firm can determine precisely the position itself in the context of industry competition. The most fundamental aspect of the selfdefining position is the assessment of the strengths and weaknesses of internal resources as they become critical of the core of competencies that differentiate companies and others. Based on their owned core competencies, company can determine what strategies that should be used to compete in the market. This logic underlies the proposition that the stronger the internal source, the proper implementation of the company's competitive strategy. Selection and implementation of competitive strategies, which include leadership cost, differentiation, focus or integration differentiation, is the company's position should be selected to obtain sustainable competitive advantage. In other words, to produce competitive advantage, not only the superior performance that should be improved, but also low cost competitive strategy should always be chosen in entering differentiation strategy as a differentiator of other companies, so companies tend to choose and implement competitive cost-competitive integration strategy. Employees who built the professionalism of internal resources through the empowerment of skills, talents, and placement according to competence to increase productivity, discipline and employee satisfaction which is responsive and proactive to change market and company expectations, so HR professional investment is capable to run an efficiently and effectively internal business processes to generate value for customers that impact on cash inflows for companies. This is according to Smith's line (2007) there are at least three learning objectives and the growth of human resources, the development of qualified employees, upgrading systems, and improving internal communication. The development of employee quality has an impact on running supply chain capabilities that can produce efficient products for new market penetration and ultimately able to generate maximum profits. System improvements will increase service, so the company's reputation will be good customer's mind and will reduce costs. Improving internal communication will bring positive impact in the ease of product acceleration, so as to build a good relationship with customers.

Small and medium-sized businesses tend to be more effective if they choose competitive focus strategy, which serving markets with sizes based on raw material processing capacity, 
production processes, packaging, and distribution, as well as a focus on a particular community that has been cultivated. Micro/small scale enterprises tend to be managed by one person with different preferences and limitations as well as the implementation of competitive strategies according to business scale and product pricing in the market. Phenomenon in the field shows that products come from small and medium-sized enterprises, which brand has not been widely recognized, sold at a cheaper price than large-scale companies that have well-known brands of powerful and large companies that generally produced on a large scale efficiently. This fact illustrates that price used by small and medium scale companies serves as basis of competition with other stronger large-scale corporate brands. This phenomenon shows that small and medium-sized companies can sell their products at lower prices than large enterprise products, at least for two factors, namely (1) lower marketing costs and (2) setting lower profit margins. When company is able to apply the right competitive strategy, company is expected to gain a competitive advantage for itself to produce superior performance compared to its competitors. Purwohandoko (2010) in his research, taking measurement of company's performance with Balanced Scorecard approach, including customer perspective, financial perspective, internal process perspectives, learning and growth perspectives. Proposition is formulated to make a stronger competitive advantage gained from the selection and implementation of corporate competitive strategy, better performance. Dollinger (1999) stated that the company is a collection of heterogeneous sources or production factors, which can result in different financial performance. The importance of strategies to produce sustainable competitive advantage can be realized if the formulation and execution of strategies based on the strength of internal resources, therefore the strength of the company's internal resources will result in the performance of the company. Barney (1991a) suggested that the company's competitive advantage lies in the 'privilege and the availability of resources which is difficult to replicate by other companies. When company is able to apply the right competitive strategy, company is expected to gain a competitive advantage for itself to produce superior performance compared to its competitors. Purwohandoko (2010) is taking measurement of company's performance with Balanced Scorecard, including customer perspective, financial perspective, internal process perspectives, learning and growth perspectives. Proposition is formulated to make a stronger competitive advantage gained from the selection and implementation of corporate competitive strategy, better performance. The company is a collection of heterogeneous sources or production factors, which can result in different financial performance. The importance of strategies to produce sustainable competitive advantage can be realized if the formulation and execution of strategies based on the strength of internal resources, therefore the strength of the company's internal resources will result in the performance of the company. Barney (1991a) and Fahy \& Alan (1999) suggested that the company's competitive advantage lies in the 'privilege and availability of resources which is difficult to replicate by other companies so that one company has the same strategy in formulating and implementing a strategy based on resources from each company. Besides, each company cannot operate the same resources as if the resources were limited. They have different priorities in allocating and assessing the importance of corporate performance. Purwohandoko, (2010) in the study, explained that in East Java, the selection and implementation of internal competitive strategies of the most dominant resource is the low cost dimension. This suggests that in general, the reputation of enterprise resources tends to be a source of corporate competitive advantage through the selection and implementation of low cost strategies. The meaning of the highest choice for low-cost strategy with internal resource variables reflects : resource (1) internally oriented exploitation gains competitive advantage from cost aspect, and (2) strategic focus tends to be applied by small-scale business scale, price competition based on the trade industry. Internal resources in the form of a portfolio of physical resources, reputation, brand strength, technology, human resources, finance, and corporate organization are meaningless if they are not used as a basis for the implementation of competitive strategies. The competitive strategies that implemented by the company depend on the internal resources of that portfolio. 


\subsection{Managerial Impact}

Internal resources in the form of a portfolio of physical resources, reputation, brand strength, technology, human resources, finance, and corporate organizations are meaningless if they are not used as a basis for the implementation of competitive strategies. Therefore, accuracy of competitive strategy choices and implemented by companies depends on the internal resources of the portfolio. Small and medium-sized enterprises tend to use a focus strategy, the extent of their market is built from a particular society, so there is not much additional cost other than production and packaging costs arising from the limited number of realized based on internal resources. Meanwhile, largescale companies tend to use cost leadership strategies because they tend to have better internal resource strength than smaller scales. However, as a result, in addition to production and packaging costs, there are many additional expenses for distribution and promotion to lucrative markets and distribution channels, to deliver products to end users. The right competitive strategy is the key to the success of the company.

Performance from the perspective of human resources is also important. Companies often try to engages their employees by doing training, education, or other forms of empowerment to improve their competencies which is able to generate productivity, thereby customer satisfaction will increases. While at the same time the employee turn-over rate will decreases. Human resources is a unique resource. Thus, companies need to build a collective awareness of all human resources to achieve the vision, mission, and goals of all units/departments with the transformation of internal resources. Therefore, to produce products based on the company's strategy, measuring the company's resources before setting the chosen strategy is critical to increasing competitive advantage. By measuring the capability of these resources, the company can optimize its core competencies.

\section{RESEARCH CONCLUSION AND LIMITATION}

This research concluded that to produce the better competitive advantage should maintain the professionalism of their internal resources by empower the employee skills, talents, uses competence placement strategies, and the others. Therefore, after the internal resources become satisfied with their current condition, they tend to get more customer values that impact on cash inflows for companies. This research also indicated that Small and Medium-sized enterprises tend to use a focus strategy as their competitive strategy, while, the large-scaled enterprises tend to use cost leadership strategies to have better internal resource strength than the others.

\subsection{Limitation}

Nevertheless, this research has some limitation. This study only uses theory comparison as the research method. Therefore, It can suggest, further research should be done in broader scale.

\section{REFERENCES}

Aaker, D. A. (1991). Managing Brand Equity. New York: Free Press.

Barney, J. B. (1991a). Firm Resources and Sustained Competitive Advantage. Journal of Management, 17(1), 99-120.

Barney, J. B. (1991b). The Resource Based View of Strategy: Origins, Implication, and Prospects. Editor of Special Theory Forum in Journal of Management, 17, 97-211.

Barney, J. B., \& Arikan, A. M. (2000). The Resource-based View: Origins and Implication. Journal of Management, 124-188.

Craig, J. C., \& Grant, R. M. (1999). Manajemen Strategi: Sumberdaya, Perencanaan, Efisiensi Biaya, Sasaran,Terjemahan. Jakarta: Elex Media Komputindo.

Collis, D. J., \& Montgomery, C. A. (1998). Corporate Strategy: A Resource-Based Approach, International Editions. The Synergy: McGraw-Hill/Irwin. 
David, F. R. (2003). Strategic Management Concept. Ninth Edition, New Jersey: Prentice Hall.

Fahy, J., \& Alan, S. (1999). Strategic Marketing and the Resource Based View of the Firm, Academy of Marketing Science Review (No. 10). Retrieved from http://www.amsreview.org/articles/fahy10-1999.pdf.

Greer, C. R. (2003). Strategic Human Resource Management, Second Edition. Pearson Custom Publishing.

Kaplan, R. S. \& Norton, D. P. (1992). Using The Balanced Score Card-Measure that Drive Performance, Harvard Business Review. Jan-Feb, 71-79.

Kaplan, R. S. \& Norton, D. P. (1996). Balanced Scorecard. Translating Strategy Into Action. New York: Harvard Business School Press.

Kaplan, R. S. \& Norton, D. P. (2004). Strategy Maps: Converting Intangible Assets Into Tangible Outcome. New York : Harvard Business School Publishing Corporation.

Makinen, H. (2000). Product Design as Core Competence in a Design Oriented Industry, Turku School of Economics and Business Administration.

Matsuno, K., Mentzer, J. T., \& Remtz, J. (2005). A Conceptual And Empirical Comparison of Three Market Orientation Scales. Journal of Business Research 58, 1-8.

Mitchell, R. C. (2004). Strategy Formulation. Retrieved from http://www.csun.eduthfmgt001/ formulation.doc

Porter, M. E. (1980). Competitive Strategy: Techniques For Analyzing Industry And Competitors. New York: The Free Press.

Porter, M. E. (1996). What is Strategy? Harvard Business Review, November-December, 61-78.

Priem, R. L. \& Butler, J. E. (2001a). Is the Resource-Based Theory a Useful Perspective for Strategic Management Research?. Academy of Management Review, 26(1), 2240 .

Priem, R. L., \& Butler, J. E. (2001b). Tautology in the Resource-Based View and Implications of Externally Determined Resource Value: Further Comments, Academy of Management Review. 26(1), 57ᄀ66.

Purwohandoko. (2010). Integrasi Sumberdaya Internal Dan Orientasi Pasar Sebagai Basis Strategi Bersaing Pada Perusahaan Air Minum Dalam Kemasan (AMDK) Di Jawa Timur. Tesis. Universitas Brawijaya Malang.

Smith, R. F. (2007). Business Process Management and The Balance Scorecard, Using Processes as Strategic Drivers. New York: John Wiley and Sons, inc.

Twomey, D. F., \& Drew, L. H. (2000). From Strategy To Corporate Outcome: Aligning Human Resources Management System With Entrepreneurial Intent. International Journal of Commerce and Management, 10, 43-55.

*) Purwohandoko, State University of Surabaya, Surabaya, Indonesia (E-Mail: warogpurwo2008@yahoo.com) 
Jurnal Ilmiah Bidang Akuntansi dan Manajemen (JEMA) Vol. 15 No. 1 (2018)

http://riset.unisma.ac.id/index.php/jema (p-ISSN : 1693-7864, e-ISSN : 2597-4071)

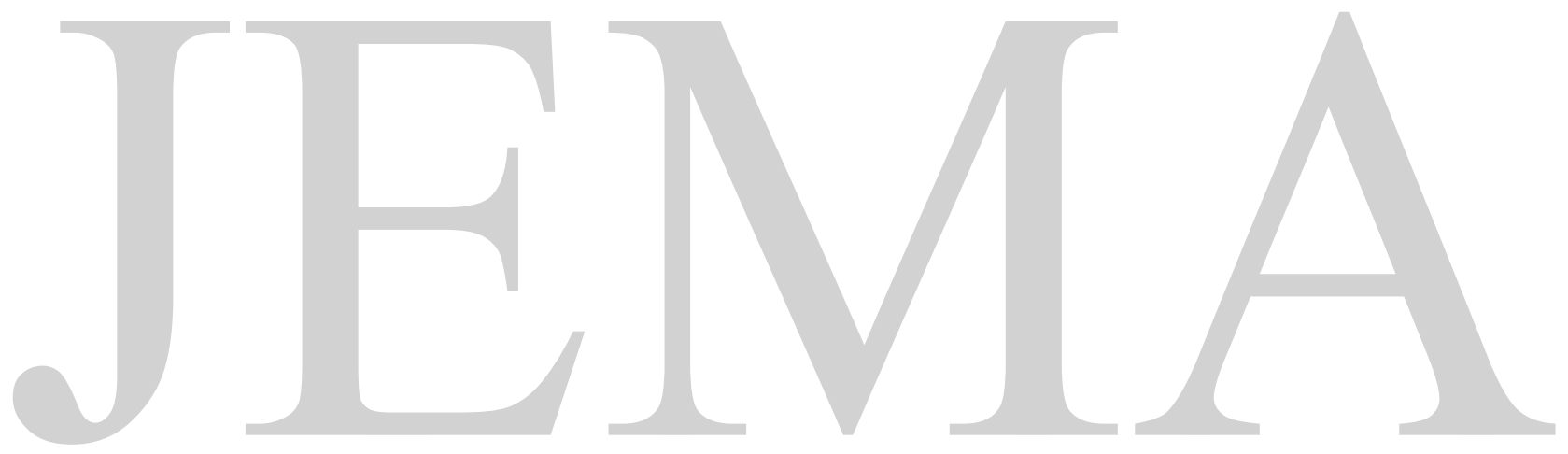

